\title{
Invasion and Nutrient Acquisition Strategies of Phytopathogens: Fungi, Bacteria and Viruses
}

\author{
Prahlad Masurkar ${ }^{1}$, Raina Bajpai ${ }^{1 *}$, Vandana Sahu ${ }^{1}$, Munnesh Kumar ${ }^{2}$ and \\ Rahul Singh Rajput ${ }^{1}$ \\ ${ }^{1}$ Department of Mycology and Plant Pathology, ${ }^{2}$ Department of Genetics and \\ Plant Breeding, Institute of Agricultural Sciences, Banaras Hindu University, \\ Varanasi, Utter Pradesh-221005, India \\ *Corresponding author
}

\begin{abstract}
A B S T R A C T
Major phytopathogens (fungi, bacteria and viruses) cause heavy damage to crop plants. The comprehensive knowledge of phytopathogens nature i.e. biotrophic, hemibiotrophic and necrotrophic, their intrusion tools by which they get entrainment in plant cell and the

\section{Keywords}

Nutrients, Haustoria,

Sporulation,

Transporters,

Metabolism etc.

Article Info

Accepted:

17 July 2018

Available Online:

10 August 2018 machinery of nutrient acquisition so we can make a better understanding about the phytopathogen. This information about phytopathogen helps us to develop novel disease control strategy against them. In this review we have tried to reveals the invasion mechanism by the phytopathogens as fungi physical invasion with help of haustoria, intacellular hyphae and cell wall degrading enzymes, bacteria do passive invasion from stomata and viruses with help of vectors they transmit in to plant cells. This review also deals with the various nutrient acquisition strategies of phytopathogens. Biotrophic fungi usually prefer carbohydrate and in adverse condition shifted towards nitrogen containing compounds whereas necrotrophic fungi get nutrients by altering cell membrane permeability of host. During sporulation of fungi, the role of mannitol is well established. Bacteria use transporters (TBDRs and $\mathrm{ABC}$ ) and porin proteins for fulfilling their nutrient hunger. During scarcity of nutrients SWEET proteins regulate the acquisition of nutrient in bacteria. Viruses by cellular reprogramming capture the host machinery of replication factories. Protein metabolism also altered during the viral infection by changing target cell for which nutrients are made by host cell so virus can multiply.
\end{abstract}

\section{Introduction}

The major plant phytopathogens are fungi bacteria and viruses in terms of infecting crop plants and losses. Approx 12\% annual crop losses are due to diseases other than nematodes (Singh, 2002). The major plant phytopathogen fungi, bacteria are biotrophic, hemibiotrophic and necrotrophic in nature, while the viruses are strictly biotrophic phytopathogen. The fungal phytopathogens have effective mechanism of invasion in to host plant to produce symptoms of disease and later their spores disseminate in to another plant and cause an epidemic. Bacteria also have strategies to enter in to plants. Bacteria 
are usually present in a film of water over a stoma and, if water soaking occurs, a bacterium swims through the stoma and then, enters in to substomatal cavity where they multiply and start infection. But in case of viruses the pathogen get entry with the help of vectors because they don't have any sign such as spores, cell wall degrading enzymes (CWDEs) and also have no machinery to multiply outside the cell. So they establish relationship with the vector to disseminates and invade the host cell. Another aspect included in this review which is being given less attention by researchers is the nutrient acquisition strategies by phytopathogens. The pathogenic behavior of phytopathogen depends upon the metabolic dependency on host. Nutrient acquisition mechanism is a two way process where phytopathogen manipulate the host machinery for deriving nutrients and then establishing the relation between host and pathogen.

After that pathogens starts to modulate host physiology according to their nutrient requirements. In case of fungi, initially fungal spore lands on the plant surface and then penetrate by forming haustoria in biotrophic fungi now the host and phytopathogen relationship established. In bacterial plant pathogen initially, bacterial pathogens colonize the plant surfaces namely, the phyllosphere and the rhizosphere and obtain nutrients. Later, majority of them gain access by entering through natural openings to the interior portions of plant tissues including the vascular elements and the intercellular spaces to obtain more nutrients and to avoid harsh and fluctuating environmental conditions (Griffin and Carson, 2015).

Apart from fungi, bacteria and viruses are different; they have complexity with their host as viral infection is limited to the indexing of physiological changes which occurs in host (van Loon, 1987).

\section{Invasion and nutrient acquisition strategies: Fungi}

The survival of any organism is totally depends upon the growth and reproduction. Fungi also do follow this process. For their growth and reproduction they require the nutrients from their host. In case of fungi the sources of nutrients were the plants. The plants have the phyllosphere (Andrews and Harris, 2000) and rhizosphere (Clark, 1949), fungi mostly get nutrients from the phylloplane (a subdivision of phyllosphere) and less through rhizoplane (a subdivision of rhizosphere). In the phylloplane, leaves serves as the nutrient source and invasion of fungi take place with according to their nature's viz. fungi are biotrophic, hemibiotrophic or necrotrophic to invade the source of nutrients. Biotrophic, hemibiotrophic and necrotrophic fungi invasion in phylloplane and rhizoplane were shown in figure 1.

\section{Biotrophs}

They relies only on the living host and shows an intimate relationship with their host. They form haustoria to absorb nutrients. Haustoria penetrate up to the leaf mesophyll cell wall and grow adjacent to the plasma membrane, without entering the cytoplasm (Latijnhauwers et al., 2003; de Wit, 2007; Kemen and Jones, 2012; Delaye et al., 2013; Kabbage et al., 2015). They also produce polyketide synthases, modular nonribosomal peptide synthetases etc. which are the key enzyme involved in the biosynthesis of secondary metabolites in fungi. The best example is Blumeria graminis having polyketide synthesis and modular nonribosomal peptide synthetases. (Spanu et al., 2010).

\section{Hemibiotrophs}

Initially they act as biotrophs and later necrotrophs. Magnaporthe grisea, 
Colletotrichum lindemuthianum are the hemibiotroph of rice and beans respectively. Conidia on the host surface germinate and form melanized appressoria that penetrate the epidermal cells (Mendgeen and Hahn, 2002).

\section{Mechanism of spore germination and invasion}

Under this process, spores disseminate and land from the source to on its host and started the process of establishment of the relationship with the host. Here spores have glycogen, trehalose, sugar alcohols (polyols) (Lewis and smith, 1967) terms of energy source, spore tip mucilage (Hammer et al., 1988) and melanized appressoria for penetration. Melanised appressoria (5-10 micron diameter) have penetration peg (0.5 micron diameter) which is narrower than appressoria and forcing turgor pressure all very small area of the host cell. Here melanin acts as an effective barrier for solutes like carbohydrate and polyols to mobilize to appressorium. Subsequent breakdown of the lipids and carbohydrates stores increase in solute concentration inside the appressorium. Glycerol is the major solute reaching a concentration of approximately 3 molars for maintaining such pressure polyols in solution required a significant amount of water which can travel into the appressorium through the melanin layer. Glycerol can't escape the melanin layer so tremendous turgor pressure is generated when water is available.

This turgor pressure is about 80 atmospheres, equivalent to 1200 PSI. If the extracellular concentration is raised so that the solute concentration is higher outside the cell than inside, Water is withdrawn from the cell and the resultant higher external pressure causes the aspersorium to collapse. The transportation of lipid occurs through the lipolysis and betaoxidation cycle. When the plant surface has the poor nutrient condition that time tricarboxylic acid cycle through acetyl coenzyme A generate ATP plays a great role in phytopathogenesis (Idnurm and Howlett, 2002; Solomon et al., 2004).

\section{Biotrophic phytopathogen during establishment in host}

After entering the host cell the energy source in spores was exhausted, now phytopathogen has to take nutrients from the host as early as possible for being established in the host. In the case of obligate biotrophs, with the help of houstoria, they established themselves (Voegele, 2006) in the host. In the hemibiotrophic, they developed some other specialized structures like intracellular hyphae (Perfect and Green, 2001). These intracellular hyphae develop a mechanism to establish a relationship with host metabolism.

The disturbance in the process of plant metabolism is due to phytopathogen. We can easily understand the relationship between plant and the phytopathogen with the help of model plant Arabidopsis thaliana and its relation with powdery mildew fungi (Fotopoulos et al., 2003). The relationship of fungi with host carbohydrate which is the main source of energy for phytopathogen but it can be shifted for the benefit during adverse condition towards nitrogen sources. In Cladosporium (biotrophic lifestyle and without houstoria) the utilization of GABA as a nitrogenous source has been documented.

Another source of energy for germination of spores is the lipids. Lipids also provide the compound that is used to generate the osmotic pressure for penetration of haustoria. After penetration fungi have sugars for further development. In a study of the early stage of infection, the scientist observed that there is sulfate starvation in Colletotrichum gloeosporioides f. sp. Malvaceae (Goodwin et al., 2000). 
When carbohydrates acquisition has completed by phytopathogen that time the host secret some reactive oxygen species molecule to activate the defense mechanism but the GABA shunt (Oliver and Solomon, 2004), uric acid (Divon et al., 2005) and mannitol serve as scavengers of ROS to protect phytopathogen in the infection process. Uric acid scavenging is observed in Fusarium oxysporum interaction with tomato and mannitol in Vicia faba.

\section{Necrotrophic phytopathogen during establishment in host}

Necrotrophs are notorious and have various phytopathogenic strategies for killing and absorbing the nutrients from the host plant cells for their growth and reproduction. Macerates the tissue by producing cell wall degrading enzymes and toxins (CWDEs) (Meinhardt et al., 2014) or can cause rot to stimulating hypersensitive reaction and control jasmonate ethylene-dependent pathways (Hommond-Kosack and Parker, 2003). These fungi actively manipulate host cellular machinery in order to suppress defense and or aid in disease progression. The nutrients by altering the expression of plant genes regulate cell membrane permeability. Certain amino acid such as methionine and serine are not supplied in sufficient quantity by the host tissue and they're by synthesis is carried out the fungus (Sweigard et al., 1998). In necrotrophic fungi A. brassicicola there are 83 glycosyltransferases that are probably involved in the assembly of polysaccharides in fungal cell wall (Cho, 2015) and the nutrient acquisition genes during infection that includes possible sources for amino acid backbones was revealed in the transcriptome analysis of $F$. granarium infection (Guldener et al., 2005). In $F$. granarium ornithine a nonProtein amino acid plays an important role transport by ornithine transporters after 2 days infection. Ornithine is intermediate in metabolic pathways such as arginine and proline biosynthesis as well as the biosynthesis of putrescine a precursor for other polyamines and pyrimidines in Aspergillus fumigatus. Ornithine signifies in virulence by the production of siderophore (Beckmann et al., 2013).

\section{Process and factors responsible for sporulation in fungi}

Fungal sporulation is a complex process requires a suitable environment and biological rhythms in the host cell (Wright, 1979; Timberlake, 1980). Generally, fungi begin to sporulate when there is a nutrient limitation in the host so they can survive in the adverse condition. To know the molecular mechanism behind sporulation of model organism taken by the researcher was as Aspergillus nidulans and Neurospora crassa (Roncal and Ugal de 2003; Sun et al., 2012). Mannitol is needed for vegetative sporulation in $S$. nodorum both in plant and in vitro (Solomon et. al., 2006; Solomon et. al., 2007). With that study on mutant stains that are not able to metabolize mannitol, the study found that subculturing of this suspension media without polyols brought the suspension of asexual sporulation. Mannitol biosynthesis in plants also occurs as observed in celery; mannitol is produced from mannose-6-phosphate (M-6-P) through the activity of an NADPH-mannose-6-phosphate reductase (M6PR). Thereafter, M-6-P converts it into mannitol-1-Phosphate (M-1-P) in the presence of the M6PR enzyme then M-1-P dephosphorylated by phosphate to mannitol (Loescher et al., 1992).

Light has also been regarded as an important stimulus for conidia formation. Several lightsensing proteins such as white Collar - 1 and vivid proteins have been recently identified as blue light photoreceptors that mediate lights induction of the rhythmic condition of Neurospora crassa (Froehlish et al., 2002; 
Schafmeier and Diernfellner, 2011). In addition some transcriptional factors eg. BLR 1 and BLR 2 are vital for photo conidiation process (Sanchez-Arregai et al., 2012).

\section{Invasion and nutrient acquisition strategies: Bacteria}

Biotrophic and hemibiotrophic bacteria have a mechanism to acquire nutrients either by modulating their own machinery or by manipulating plant cell mechanism. In case of modulating self-machinery, bacteria secrete some cell wall degrading enzymes (CWDEs). Now it is well known that plant cell made up of cellulose, pectin, hemicellulose and protein which is degraded by CWDEs and secreted by the TIII SS of gram -ve bacteria. In the apoplast, plant cell wall degrading enzymes disrupt the plant cell wall and liberate nutrients for the consumption of the growing bacterial population. Sucrose specific phosphotransferase system uptake sucrose in the form of sucrose 6 phosphates and catabolize into fructose and glucose 6 phosphates. In this process, tricarboxylic acid cycle plays an important role (TCA cycle).

\section{Entry points of Bacterial phytopathogens}

Most of the bacterial phytopathogens are passive invaders to plant. In aerial surface, bacteria generally, enter through the natural openings mostly by the means of stomata. In phylloplain, the leaves inhabiting stomata (Lindlow, 2002) and in rhizoplane (Lindow, 2003), the expanding roots point serves as the invasion sites (Fig. 1). Other than stomata there are sites of plant organs such as the base of trichomes, at the epidermal cell wall junctions especially grooves along the veins and near hydathodes (Bashan et al., 1981; Leben, 1969). The most common entry point that bacteria choose is stomata because this point provide bacteria not only the access substomatal chamber but to a vast array of interconnected spaces within a mesophyll. However, there also have been to evidence that stomata restrict the entry of phytopathogenic bacteria as a part of the plant immune system. But some biotrophic bacteria have evolved a sophisticated strategy for manipulating the plant immunity which is caused due to hormones such as jasmonic acid. The phytopathogenic bacteria $P$. syringae produce a coronatine (COR) a mimic of jasmonate (JA) phytohormone JAisoleucine (JA-Ile) that altered the plant defense system (Fonseca et al., 2009b). The researcher found that the COR and jasmonate isoleucine (JA-Ile) co-receptor JAZ2 is constitutively expressed in guard cells and modulates stomatal dynamics during the bacterial invasion. The existence of a COI1JAZ2-MYC 2, 3, 4-ANAC19, 55, 72 module responsible for the regulation of stomatal aperture that is hijacked by bacterial COR to promote infection (Gimenez-Ibanez et al., 2016). A recent finding suggests that not only COR but also T3SEs JAZ proteins for degradation in either a COI-1 depended and COL-1 independent to promote stomatal opening (Melotto et al., 2017).

\section{The bacterial strategy of nutrient acquisition}

Bacterial phytopathogen modulates the host machinery to obtain nutrients from the host. For obtaining nutrients bacteria use transporters. Porin protein that is presents in the outer membrane of gram -ve bacteria mediate the diffusion of small hydrophobic molecules and allow the passive diffusion of nutrients available in plant niche. Porin proteins are well studied in Pseudomonas (Delmotte et al., 2009). Bacteria also have the different type of transporters for active uptake of nutrients. Ton B- dependent transporter is present in outer membrane proteins and known as Ton B dependent receptors (TBDRs) and plays the role of active transport 
of iron-siderophore complexes in gram -ve bacteria. Ton B transporters present in Xanthomonas campestris var. campestris have a very high affinity with sucrose, suggesting that it might be sucrose scavenger. The TBDRs is works with an inner membrane transporter, amylosucrase and a regulator to utilize the sucrose, thus defining a new type of carbohydrate utilizing locus (CTU). CTU locus involves, a TBDR for the transport of sucrose across the outer membrane (Blanvillain et al., 2007). The studies on TBDRs shows that bacterial phytopathogenesis is adapted to live in poor environments by scavenging the plant carbohydrate by these transporters.

Other transporters in bacteria are the $\mathrm{ABC}$ transporters (ATP-binding cassette). There is 2 type of transportation take place in bacterial cell: one is ATP hydrolysis (primary transporters) next transportation is by conversion of potential energy to a chemical gradient of another molecule (secondary transporters).

ABC transporters help us to understand the ATP hydrolysis-driven transport mechanism (Wilkens, 2015). ABC transporters operate in a single direction either export or import. Best characterized $\mathrm{ABC}$ transporter are observed in E. coli for maltose (Chen, 2013; Oldham and chevy, 2011) and Vitamin B12 (Korkhev et al., 2012; Li et al., 2014; Locher et al., 2002) uptake system.

Other studies indicate that bacterial phytopathogen preferentially utilises some carbon sources over others. Therefore the highly expressed gene encoding transporters that are specifically facilitate the uptake of preferred carbon sources present in the niche. For example, some species of Pseudomonas and Xanthomonas utilises dicarboxylate such as malate, citrate, and succinate over other carbon sources present in the apoplast.
Nutrient acquisition during the scarcity of nutrients

Another strategy of a bacterial phytopathogen to utilize less preferred nutrients because lack of desired nutrients and i.e. in vitro condition, glucose is preferred carbon source for Ralstonia solanacearum but in natural condition when colonizing in the xylem of tomato it prefers sucrose (Jacobs et al., 2012). In mice infected by Xoo, SWEET proteins are upregulated and sucrose accumulates in apoplast readily to be used for phytopathogen growth (Chen et al., 2010; 2012). In grapevine a sequential regulation of sucrose transporter gene which is first downregulated during infection by stolbur phytoplasma to limit the spread and then upregulated during the recovery stage providing necessary nutrients (Santi et al., 2013a, 2013b). The sucrose utilizing the system of enteric bacteria has been studied in Klebsiella pneumoniae and in some isolates of E. coli and Salmonella species (Spenzer et al., 1988; Schmid, 1982). In E. coli and Salmonella species the conjugative plasmid pUR 400 confers the ability to utilize sucrose where the sucrose regulation of Klebsiella pneumoniae is located on the chromosome (Postma et al., 1993). The uptake of sucrose is mediated via the phosphoenol pyruvate dependent carbohydrate phosphotransferase system (PTS) yielding sucrose 6 phosphates and fructose.

\section{Invasion and nutrient acquisition strategies: virus}

Plant viruses are totally biotrophic; they transmit through vectors in plants by a different mechanism as nonpersistent, semipersistent, persistence circulative, nonpropagative and persistent circulative propagative (Dietzen et al., 2016). In many cases it causes symptomatic phenotypes of disease. The virus interference causes the disruption of the plant physiology. At the 
molecular basis we came to know the genes which were involved to induce or reduce the symptoms, cell cycle control and endogenous transport of macromolecules. And these genes are evidence of such type of processes. Recent findings are available which shows the interplay between the plant defense and viral particles.

\section{Virus transmission into plant host cells}

Majority of viruses get transmissible by vectors but some of them also transferred by mechanically/ sap (TMV, PVY), seed (Soybean Mosaic Virus) pollen (Alfalfa Cryptic Virus-1) fungi (Tobacco Necrosis Virus) nematode (Grapevine Fan Leaf Virus) and in last by humans (Shastry, 2013; Card et al., 2013; Hull 2004b, Brunt et al., 1995). But the transmission by vectors has great significance and this can be explained through virus vector relationship. There is in major cases four types of insect vector relationship i.e. (i) Non-persistent (ii) Noncirculative Semi-Persistent (iii) Persistent circulative (iv) Persistent propagative.

Nonpersistent- Retained in stylet or forget. There are two strategies i.e. capsid strategy and helper strategy recognized in case of nonpersistent where insect transmit the virus in an circulative manner (Blanc et al., 2014). The example of this relationship is CaMV transmission by the aphid where transmission requires interaction between CaMV encoded proteins i.e., p2 interacts with aphid stylet and p3 anchored with virion capsid cell (Hon et al., 2010). Noncirculative semi persistent- In this transmission the vectors are several like aphids whiteflies and leafhoppers. Their relations with a virus for the longer time then virus transferred by non-persistent manner ( $\mathrm{Ng}$ and Falk, 2006) and they are lost by viruliferous vectors during molting. The example of this type of transmission is lettuce infectious yellow virus (LIYV) transmitted by
Bemisia tabaci. Persistent circulative- In this transmission, virus are acquired by their vectors through their mouthparts and get accumulated internally, than they are passed through their tissues to introduce the plant again with mouthparts of the vector. The best example is begomovirus transferred by $B$. tabacci (Rosen et al., 2015).

Persistent propagative- In this type of transmission virus replicate in insect circulatory system and induced viral inclusions (Kobayash et al., 2006; Moroniche et al., 2010). Here when virus ingested by insect vector correlate initial infection in to midgut epithelium and then transfer to midgut visceral muscles (Gutierrez et al., 2013) then spread in to haemocoel through salivary gland and horizontally transferred to healthy plants or transovarial transferred to offsprings (Hogenhout et al., 2008; Lequime et al., 2014). Rice stripe virus with planthopper has a persistent propagative relationship.

Plant infected with virus showed the gradual decrease in net photosynthesis and also altered in carbohydrate metabolism (Shaltin and Wolf, 2000) in CMV infected plants. Plants expressing virus symptoms having virusencoded movement proteins and dilated plasmodesmata due to these, alteration of movement of primary metabolites such as starch and soluble sugars and decreased photosynthesis and increased respiration is observed (Tecsi et al., 1996; Balchandran et al., 1997; Herbers et al., 2000). These alterations in physiology of plant suggested that virus-infected leaves act as a sink. The allocation of carbohydrate depends upon virus-encoded membrane proteins (MPs) and plasmodesmata (PDs) size expansion. Several workers demonstrated that leafroll virus-3 in grapevine causes a disruption in transport and accumulation of photosynthetic assimilates such as sucrose (Endeshawet et al., 2014; Montero et al., 2016 a b c). 
Fig.1 Schematic representation of entry, establishment and invasion of different phytopathogens in plants

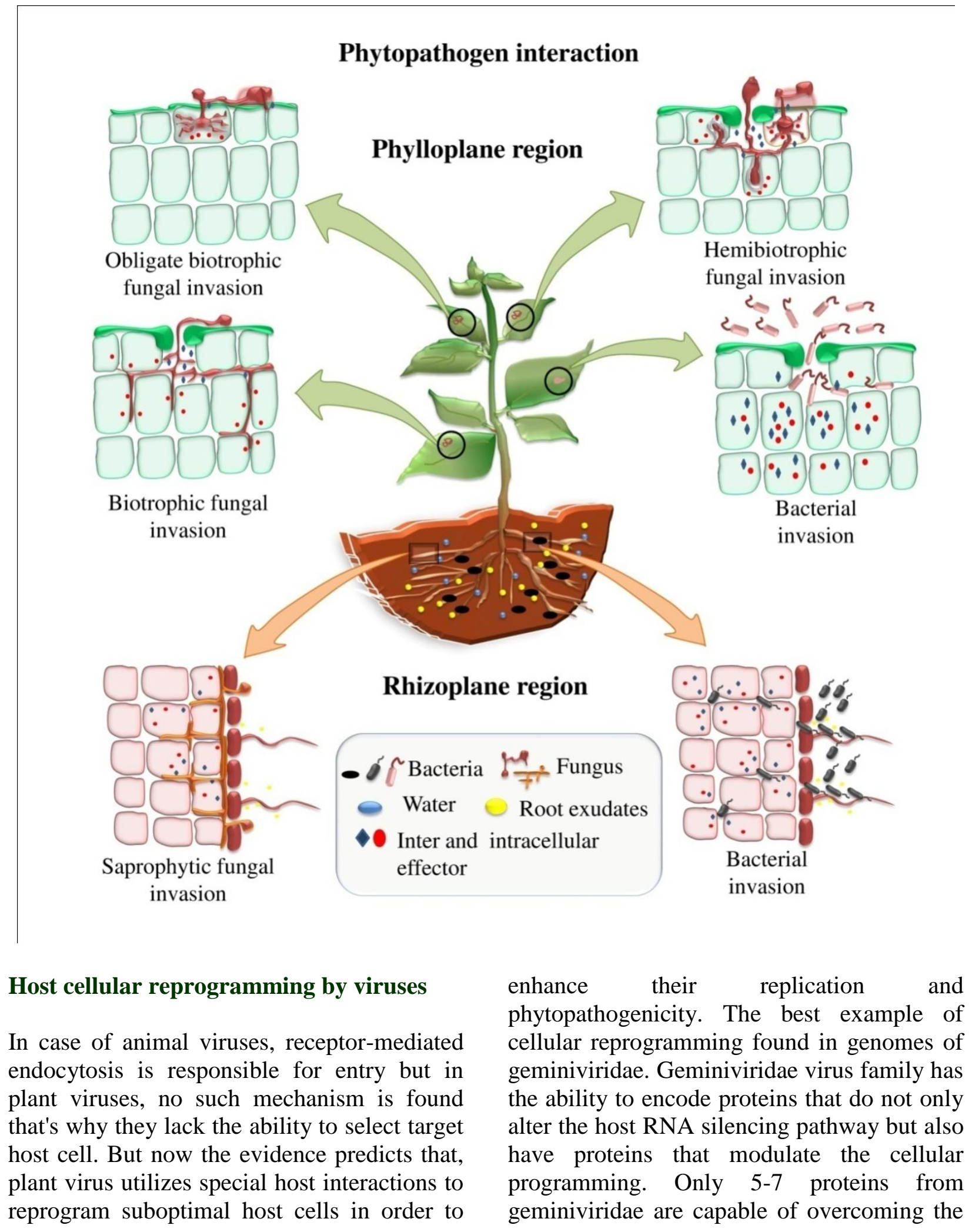


defense strategies of the plant due to the complex nature of a protein that presents in Geminiviruses. Well planned membrane alteration of viruses leading to the production of replication factories. These replication factories are the result of the action of the one or more viral proteins (Kovalev et al., 2016). Viral replication proteins contribute more for alteration of inner membrane which can be done by capturing and recruit the host proteins or RNA to replication sites, leading to membrane deformation (Jin et al., 2017).

\section{Protein metabolism during viral infection}

Manipulation of host protein in plant either done by upregulation of proteins or by downregulation of them according to a need of viruses. Proteomics studies show the upregulation of methionine synthase and ornithine carbamoyltransferase level during papaya meleira virus (PmeV) infection (SerraSoriyana et al., 2015). Another amino acid i.e. phosphoglycerate dehydrogenase was upregulated during infection with rice yellow mottle virus (RYMV) (Ventelan-Debout et al., 2004). In spite of these changes, downregulation was also observed in case of glutamate synthase and cysteine synthase during PmeV infection and RBSDV infection (Rodrigues et al., 2011; Li et al., 2011). Proteins of the host are regulated by some viruses like tomato bushy stunt virus (Panayas et al., 2005) Brome mosaic virus (Kushner et al., 2003), and influenza virus strain H1N1 and H5N4 (Karlas et al., 2010). These viruses are also helping us to identify the cellular metabolism pathways, indicating the importance of cellular metabolism for virus infection.

Under protein metabolism of host, well documentation has been made on geminiviruses where the majority of viral proteins interacted with plant proteins. These viral proteins altered the plant developmental and defense processes by interacting with plant ubiquitination, small ubiquitin-like modifier (SUMO) and protease-mediated degradation machinery. The alteration or modification in host cell protein metabolism helps the virus to multiply in a host by changing the target cell for which nutrients are made (Ramesh, 2017). There is downregulation of heat shock protein (HSP) when there is the infection of tomato yellow leaf curl virus (TYLCV) in the host. HSPs mainly HSP70 and HSP 90 involved in TYLCV infection. HSP70 and HSP 90 also act as cellular chaperones. HSP70 and HSP 90 with viral proteins, ubiquitin, 26s proteasome subunits and autophagy unit ATG 68 are composed a large protein aggregate and can be considered as markers of a successful virus invasion (Goronits et al., 2016).

The plant pathogens viz. fungi, bacteria, and virus have a different mechanism of invasion in the host. Only a few propagules (fungi and bacteria) of phytopathogen come in to contact with the host and complete infection cycle.

During the process of infection, these phytopathogens require energy for their development and they got this by manipulating host machinery. This review reveals the fungal process of invasion which achieved by tools like haustoria (biotrophic), intracellular hyphae (hemibiotrophic) and CWDEs (necrotrophic). For nutrient niches leaves are the principle source where the photosynthetic (carbohydrate) product stores primarily. Later when insufficiency of primary photosynthetic product the fungi shifted toward the nitrogen source i.e. GABA (in Cladosporium). The second energy source of phytopathogenic fungi is the lipids. Necrotrophic phytopathogen gets nutrients with shift in membrane permeability. During sporulation, mannitol provides as a source of energy to spores. 
In case of bacteria passive entry points mostly are stomata in plant leaves. In spite of stomata lenticels and hydathodes etc. are also used by bacteria for entry. Proteomic studies reveal that the COR-induced stomatal reopening requires perception by $\mathrm{COI} 1$ receptor and further studies reveals that COI1 requires the JAZ co-receptor. For obtaining nutrient bacteria is utilizes the porin proteins and transporters i.e. TBDRs which act as CTU. This CTU with TBDRs involves the transport of sucrose across the outer membrane. Another transporter is $\mathrm{ABC}$ transporters with the primary transporter and secondary transporter. When there is a scarcity of nutrients during bacterial infection bacteria upregulate SWEET protein which accumulates the sucrose in cells. The uptake of sucrose is mediated via phosphoenolpyruvate (PEP) dependent carbohydrate phosphotransferase system. With this review we also conclude that viruses get the entry into plants by means of vectors and vector virus relationship observed i.e. (i) Nonpersistent (ii) Noncirculative semiPersistent (iii) Persistent circulative (iv) Persistent propagative. Nutrient acquisition by viruses is the underdeveloped field of study. Here cellular reprogramming studies have been made where alteration of the host RNA silencing occurs. Another strategy where protein metabolism has been discussed is PmeV infected plant where protein down regulated and upregulated seen. The protein metabolism also observed in BMV (Brome Mosaic Virus) and H1N1, H5N4 influenza viruses. There has been the great role of SUMO also has been coming up with research in protein metabolism. The heat shock protein (HSP70 and HSP90) plays a twist in successful invasion machinery.

\section{References}

Andrews, J. H. and Harris, R. F. 2000. The ecology and biogeography of microorganisms of plant surface. Annual Rev. Phytopath. 38: 145-180.

Balachandran, S., Hurry, V. M., Kelley, S. E., Osmond, C. B., Robinson, S. A., Rohozinski, J..1997. Concepts of plant biotic stress. Some insights into the stress physiology of virus-infected plants, from the perspective of photosynthesis. Physiol Plant. 100: 203-213.

Bashan, Y., Sharon, E., Oleon, Y., Henis, Y. 1981. Scanning electron and ligbl microscopy of infection and symptom development in tomato leaves infected with Pseudomonas tomalo. Physiol Plant Palhol. 19 (1): 3944.

Beckmann, N., Schafferer, L., Schrettl, M., Binder, U., Talasz, H., Lindner, H., Haas H. 2013. Characterization of the link between ornithine, arginine, polyamine and siderophore metabolism in Aspergillus fumigatus. PLoS ONE 8:e67426.

Blanc, S., Drucker, M., Uzest, M. 2014. Localizing viruses in their insect vectors. Annu Rev Phytopathol. 52: 403-425.

Blanvillain, S., Meyer, D., Boulanger, A., Lautier, M., Guynnet, C., Denance N., Vasse, J., Lauber, E., Arlat, M., 2007. Plant Carbohydrate Scavenging through TonB Dependent Receptors: A Feature Shared by Phytopathogenic and Aquatic Bacteria. PLoS ONE 2(2): e224.

Brunt, A., Crabtree, K., Dallwitz, M., Gibbs, A., Watson. L. 1996. Viruses of plants: descriptions and lists from the VIDE database. (CABI International: Wallingford).

Card, S., Pearson, M., Clover, G. 2007. Plant phytopathogens transmitted by pollen. Austral Plant Pathol. 36: 455-461.

Chen, J. 2013. Molecular mechanism of the Escherichia coli maltose transporter. Current opinion in structural biology. 23: 492-8.

Chen, L. Q., Hou, B. H., Lalonde, S., Takanaga, H., Hartung, M. L., Qu, X. Q. 2010. Sugar transporters for intercellular exchange and nutrition of 
phytopathogens. Nature. 468: 527-532.

Chen, L. Q., Qu, X. Q., Hou, B. H., Sosso, D., Osorio, S., Fernie, A. R. 2012. Sucrose efflux mediated by SWEET proteins as a key step for phloem transport. Science. 335: 207-211.

Cho, Y. 2015. How the Necrotrophic Fungus Alternaria brassicicola Kills Plant Cells Remains an Enigma. Eukaryot Cell. 14:335-344.

Clark, F. E. 1949. Soil microorganisms and plant roots. Advances in Agronomy. 1: 241-288.

De Wit, P. J. G. M. 1977. A light and scanningelectron microscopic study of infection of tomato plants by virulent and avirulent races of Cladosporium fulvum-infected tomato. Plant Mol Biol 22: 1017-1029.

De Wit, P. J. G. M. 2007. Visions and reflections. How plants recognize phytopathogens and defend themselves. Cell Mol Life Sci. 64: 2726-2732.

Delaye, L., Guzmán, G. G., Heil, M. 2013. Endophytes versus biotrophic and necrotrophic phytopathogens are fungal life-styles evolutionarily stable traits? Fungal Diverse. 60: 125-135.

Delmotte, N., Knief, C., Chaffron, S., Innerebner, G., Roschitzki, B., Schlapbach, R., 2009. Community proteogenomics reveals insights in to the physiology of phyllosphere bacteria. Proc.Natl.Acad.Sci.U.S.A. 106: 1642816433.

Dietzgen Ralf, G. Mann S. K. and Karyn J. N. 2016. Plant Virus-Insect Vector Interactions: Current and Potential Future Research Directions. Viruses. 8 (11): 303.

Divon, H.H., Rothan-Denoyes, B., Davydov, O., Di Pietro, A. and Fluhr, R. 2005. Nitrogen-responsive genes are differentially regulated in planta during Fusarium oxysporum f. sp. Lycopersici infection. Mol. Plant Pathol. 6: 459 - 470.

Duncan, K. E. and Howard, R. J. 2000. Cytological analysis of wheat infection by the leaf blotch phytopathogen Mycosphaerella graminicola. Mycol Res. 104: 1074-1082.
Endeshaw, S. T., Murolo, S., Romanazzi, G., Schilder, A. C., Neri, D. 2014. Effects of grapevine leafroll associated virus 3 infection on growth, leaf gas exchange, yield and basic fruit chemistry of Vitis vinifera L. cv. Cabernet Franc. Sci Hortic. 170: $228-236$

Fotopoulos, V., Gilbert, M. J., Pittman, J. K., Marvier, A. C., Buchanan, A., Sauer, N., Hall, J. L., Williams, L. E. 2003. The monosaccharide transporter gene, AtSTP4, and the cell-wall invertase, Atbfruct1, are induced in Arabidopsis during infection with the fungal biotroph Erisyphe cichoracearum. Plant Physiol 132: 821-829.

Froehlich, A. C., Liu, Y., Loros, J. J., Dunlap, J. C. 2002. White Collar-1, a circadian blue light photoreceptor, binding to the frequency promoter. Science. 297(5582): 815-819.

Froehlich, A. C., Liu, Y., Loros, J. J., Dunlap, J. C. 2002. White collar-1, a circadian blue light photoreceptor, binding to the frequency promoter. Science 297: 815819.

Gimenez-Ibanez, S., Boter, M., Ortigosa, A., Garcia-Casado, G., Chini, A., Lewsey, M. G., Ecker, J. R., Ntoukakis, V. Solano, R. 2016. JAZ2 controls stomata dynamics during bacterial invasion. New Phytologist. 213: 1378-1392.

Goodwin, P. H., Li, J. and Jin, S. 2000. Evidence for sulfate depression of an arylsulfatase gene of Colletotrichum gloeosporioides f. sp. Malvae during infection of round-leaved mallow, Malva pusilla. Physiol Mol Plant Pathol. 57: 169-176.

Gorovits, R., Lui, Y., Czosnec, H. 2016. The Involvement of HSP70 and HSP90 in Tomato Yellow Leaf Curl Virus Infection in Tomato Plants and Insect Vectors. In: Heat Shock Proteins: Heat Shock Proteins and Plants. (Eds.) A. A. A. Alexzander - and S. K. Calderwood Pp. 189-191 10.

Griffin, E. A., and Carson, W. P. 2015. The ecology and natural history of foliar bacteria with a focus on tropical forests 
and agroecosystems. Bot Rev. 81, 105149.

Gutierrez, S., Michalakis, Y., VanMunster, M., Blanc, S. 2013. Plant feeding by insect vectors can affect life cycle, population genetics and evolution of plant viruses. Funct Ecol. 27: 610-622.

Hamer, J. E., Howard, R. J., Chumley, F. G., Valent, B. 1988. A mechanism for surface attachment in spores of a plant phytopathogenic fungus. Science. 239 (4837): 288-290.

Hammond-Kosack, K. E., Parker, J. E. 2003. Deciphering plant-phytopathogen communication: fresh perspectives for molecular resistance breeding. Curr Opin Biotechnol. 14: 177-193.

Herbers, K., Takahata, Y., Melzer, M., Mock, H. P., Hajirezaei, M., Sonnewald, U. 2000. Regulation of carbohydrate partitioning during the interaction of potato virus $\mathrm{Y}$ with tobacco. Mol Plant Pathol. 151-59

Hogenhout, S. A., Ammar, E. D., Whitfield, A. E., Redinbaugh, M. G. 2008. Insect vector interactions with persistently transmitted viruses. Annu Rev Phytopathol. 46: $327-$ 359.

Hoh, F., Uzest, M., Drucker, M., PlissonChastang, C., Bron, P., Blanc, S., Dumas, C.2010. Structural insights into the molecular mechanisms of cauliflower mosaic virus transmission by its insect vector. J Virol. 84: 4706-4713.

Idnurm, A., Howlett, B. J. 2002. Isocitrate lyase is essential for phytopathogenicity of the fungus Leptosphaeria maculans to Canola (Brassica napus). Eukaryot. Cell 1:719-724.

Jin, X., Cao, X., Wang, X., Jiang, J., Wan, J., Laliberte, J. and Zhang, Y. 2018. Three dimensional Architecture and Biogenesis of Membrane Structures Associated with Plant Virus Replication. Frontiers in Plant Science. 9: (57).

Kabbage, M., Yarden, O., Dickman M. B. 2015. Phytopathogenic attributes of Sclerotinia sclerotiorum: switching from a biotrophic to necrotrophic lifestyle. Plant Sci. 233: 53-60.

Karlas, A., Machuy, N., Shin, Y., Pleissner, K. P., Artarini, A., Heuer, D., Becker, D. Khalil, H., Ogilvie, L. A., Hess, S. 2010. Genome-wide RNAi screen identifies human host factors crucial for influenza virus replication. Nature. 463: 818-822.

Kemen, E. and Jones, J. D. G. 2012. Obligate biotroph parasitism: can we link genomes to life-styles? Trends in Plant Sci. 17: 448-457.

Kobayashi, T., Chappell, J. D., Danthi, P., Dermody, T. S. 2006. Gene-specific inhibition of reovirus replication by RNA interference. J Virol. 80: 9053-9063.

Kovalev, N., De Castro Martin, I. F., Pogany, J., Barajas, D., Pathak, K., Risco, C. 2016. Role of viral RNA and co-opted cellular ESCRT-I and ESCRTIII factors in formation of tombusvirus spherules harboring the tombus virus replicase. $\mathbf{J}$ Virol. 90: 3611-3626.

Kushner, D. B., Lindenbach, B. D., Grdzelishvili, V. Z., Noueiry, A. O., Paul, S. M., Ahlquist, P. 2003. Systematic, genome-wide identification of host genes affecting replication of a positive-strand RNA virus. Proc Natl Acad Sci U S A. 100: 15764-15769.

Latijnhouwers, M., de Wit, P. J. G. M., Govers, F. 2003. Oomycetes and fungi: similar weaponry to attack plants. Trends Microbiol. 11: 462-469.

Leben, C. 1969. Colonization of soybean buds by bacteria: observations with the scanning electron microscope. Can J MicrobioL. 15 (3): 19-20.

Lequime, S., Lambrechts, L. 2014. Vertical transmission of arboviruses in mosquitoes: a historical perspective. Infect Genet Evol. 28: 681-690.

Lewis, D. H., Smith, D. C. 1967. Sugar Alcohols (Polyols) in Fungi and Green Plants. I. Distribution, Physiology and Metabolism. The New Phytologist. 66 (2): 143-184.

Li, J., Jaimes, K. F., Aller, S. G. 2014. Refined structures of mouse Pglycoprotein. 
Protein science: a publication of the Protein Society. 23: 34-46.

Li, K., Xu, C., Zhang J. 2011. Proteome profile of maize (Zea mays L.) leaf tissue at the flowering stage after long-term adjustment to Rice black-streaked dwarf virus infection, Gene 485: 106-113.

Lindow, S. E. 2002. Differential survival of solitary and aggregated cells of Pseudomonas syringae on leaves. Phytopathology 92: S97.

Lindow, S. E., Brandl, M. T. 2003. Microbiology of the phyllosphere. Appl Environ Microbiol. 69: 1875-1883.

Locher, K. P., Lee, A. T., Rees, D. C. 2002. The E. coli BtuCD structure: a framework for $\mathrm{ABC}$ transporter architecture and mechanism. Science (New York, N.Y.) 296: 1091-8.

Loescher, W. H., Tyson, R. H., Everard, J. D., Redgwell, R. J. and Bieleski, R. L. 1992. Mannitol synthesis in higher plants. Evidence for the role and characterization of a NADPH dependent mannose-6phosphatereductase. Plant Physiol., 98: 1396-1402.

Maroniche, G. A., Mongelli, V. C., Peralta, A. V., Diste,' fano, A. J., Llauger, G., Taboga, O. A., Hopp, E. H., del Vas, M. 2010. Functional and biochemical properties of Mal de Ri'o Cuarto virus (Fijivirus, Reoviridae) P9- 1 viroplasm protein show further similarities to animal reovirus counterparts. Virus Res. 152: 96103.

Meinhardt, L.W., Costa, G. G. L., Thomazella, D. P. T., Teixeira, P. J. P. L., Carazzolle, M. F., Schuster, S. C., Carlson, J. E., Guiltinan, M. J., Mieczkowski, P., Farmer, A., Ramaraj, T., Crozier, J., Davis, R. E., Shao, J., Melnick, R. L., Pereira, G. A. G., Bailey, B. A. 2014. Genome and secretome analysis of the hemibiotrophic fungal phytopathogen, Moniliophthora roreri, which causes frosty pod rot disease of cacao: mechanisms of the biotrophic and necrotrophic phases. BioMed Central Genomics. 15: 164-189.
Melloto, M., Zhang, L., Oblessuc, P. R., Li, S. R. 2017. Stomatal Defense a Decade Later. Plant Physiology. 174: 561-571.

Montero, R., El Aou-ouad, H., Flexas, J., Bota., J. 2016. Effects of Grapevine leafroll associated virus 3 (GLRaV-3) on plant carbon balance in Vitis vinifera L. cv. GiróRos. Theor Exp Plant Physiol. 28: 110.

Ng, J. C., Falk, B. W. 2006. Virus-vector interactions mediating nonpersistent and semipersistent transmission of plant viruses. Annu Rev Phytopathol. 44: 183212.

Oldham, M. L., Chen, J. 2011. Snapshots of the maltose transporter during ATP hydrolysis. Proceedings of the National Academy of Sciences of the United States of America. 108:15152-6.

Oliver, R. P., Solomon, P. S. 2004. Does the oxidative stress used by plants for defence provide a source of nutrients for phytopathogenic fungi? Trends in Plant Science 9: 472-473.

Panavas, T., Serviene, E., Brasher, J., Nagy, P. D. 2005. Yeast genome-wide screen reveals dissimilar sets of host genes affecting replication of RNA viruses. Proc Natl Acad Sci U S A. 102: 7326-7331.

Perfect, S. E. and Green, J. R. 2001. Infection structures of biotrophic and hemibiotrophic fungal plant phytopathogens. Molecular plant pathology 2(2): 101-108.

Postma, P. W., Lengeler, J. W. and Jacobson G. R. 1993. Phosphoenolpyruvate: carbohydrate phosphotransferase systems of bacteria. Microbiol Rev. 57: 543-594

Postma, P. W., Lengeler, J. W., Jacobson, G. R. 1993. Phosphoenolpyruvate: carbohydrate phosphotransferase systems of bacteria. Microbiol Rev. 57:543-594.

Ramesh, S. V., Sahu, P. P., Prasad, M., Praveen, S. and Pappu, H. R. 2017. Geminiviruses and Plant Hosts: A Closer Examination of the Molecular Arms Race. Viruses. 9: 256.

Rodrigues, S.P., Ventura, J.A., Aguilar, C., Nakayasu, E.S., Almeida, I.C., Fernandes, 
P.M.B., Zingali, R.B. 2011. Proteomic analysis of papaya (Carica papaya L.) displaying typical sticky disease symptoms. Proteomics. 11: 2592-2602.

Roncal, T., Ugalde, U. 2003. Conidiation induction in Penicillium. Res Microbiol. 154(8): 539-546.

Rosen, R., Kanakala, S., Kliot, Adi, Pakkianathan, B. C., Farich, B. A., Magal, N. S., Elimelech M., Kontsedalov, S., Lebedev, G., Cilia, M. and Ghanim, M. 2015. Persistent, circulative transmission of begomoviruses by whitefly vectors. Current Opinion in Virology. 15: 1-8.

Sanchez-Arregui, A., Perez-Martinez, A. S., Herrera-Estrella, A. 2012. Proteomic analysis of Trichoderma atroviride reveals independent roles for transcription factors BLR-1 and BLR2 in light and darkness. Eukaryot Cell. 11(1): 30-41.

Santi, S., De Marco, F., Polizzotto, R., Grisan, S., Musetti, R. 2013a. Recovery from stolbur disease in grapevine involves changes in sugar transport and metabolism. Front Plant Sci. 4: 171.

Santi, S., Grisan, S., Pierasco, A., Marco, F., Musetti, R. 2013b. Laser microdissection of grapevine leaf phloem infected by stolbur reveals site-specific gene responses associated to sucrose transport and metabolism. Plant Cell Environ. 36: 343-355.

Sastry, K. S. 2013. Seed-borne plant virus diseases. Springer Science \& Business Media Pp. 67-73.

Schafmeier, T., Diernfellner, A. C. R. 2011. Light input and processing in the circadian clock of Neurospora. FEBS Lett. 585(10): 1467-1473

Schmid, K., Schupfner, M. and Schmitt. R. 1982. Plasmid-mediated uptake and metabolism of sucrose by Escherichia coli K-12. J Bacteriol. 151:68-76

Schuler, D., Wahl, R., Wippel, K, Vranes, M., Munsterk otter, Sauer, N. and Jorg Camper. 2015. Hxt1, a monosaccharide transporter and sensor required for virulence of the maize phytopathogen
Ustilago maydis. New Phytologist. 206: 1086-1100.

Serra-Soriano, M., Navarro, J.A., Genoves, A., Pallás, V. 2015. Comparative proteomic analysis of melon phloem exudates in response to viral infection. J Proteom. 124: 11-24.

Shalitin, D., Wolf S. 2000. Cucumber Mosaic Virus Infection Affects Sugar Transport in Melon Plants. Plant Physiology. 123(2): 597-604.

Singh R S. 2002. Introduction to principles of plant phytopathogens. Oxford and IBH. Pp.

Solomon, P. S, Waters, O. D. C. and Oliver, R. P. 2007. Decoding the mannitol enigmain filamentous fungi. TrendsMicrobiol. 15: 257-262.

Solomon, P. S., Lee, R. C., Wilson, T. J. G., Oliver, R. P. 2004. Phytopathogenicity of Stagonospora nodorum requires malate synthase. Mol. Microbiol. 53: 1065-1073.

Solomon, P. S., Waters, O. D., Jorgens, C. I., Lowe, R. G., Rechberger, J., Trengove, R. D. 2006. Mannitol is required for asexual sporulation in the wheat phytopathogen Stagonospora nodorum (glumeblotch). J Biochem. 399: 231-239.

Spanu, P. D., Abbott, J. C., Amselem, J., Burgis, A., Soanes, D. M., Stüber, K., Themaat, E. V. L. V., Brown, J. K. M., Butcher, S. A., Gurr, S. J., Lebrun, M. H, Ridout, C. J., Lefert, P. S, Talbot, N. J., Ahmadinejad, N., Ametz, C., Barton, G. R, Benjdia, M., Bidzinski, P., Bindschedler, L. V., Brewe, M. T., Davidson, L. C., Davidson, M. M. C., Collemare, J., Cramer, R., Frenkel, O., Godfrey, O., Harriman, J., Hoede, C., King, B. C., Klages, S., Kleemann, J., Knoll, D., Koti, P. S., Kreplak, J., LópezRuiz, F. J., Lu, X., Maekawa, T., Mahanil, S., Micali, C., Milgroom, M. G., Montana, G., Noir, S., O'Connell, R. J., Oberhaensli, S., Parlange, F., Pedersen, C., Quesneville, H., Reinhardt, R., Rott, M., Sacristán, S., Schmidt, S. M., Schön, M., Skamnioti, P., Sommer, H., Stephens, A., Takahara, H., Christensen, H. T., 
Vigouroux, M., WeBling, R., Wicker, T., Panstruga, R. 2010. Genome expansion and gene loss in powdery mildew fungi reveal tradeoffs in extreme parasitism. Science. 330: 1543-1545.

Sprenger, G. A., and J. W. Lengeler. 1988. Analysis of sucrose catabolism in Klebsiella pneumoniae and Scr1 derivates of Escherichia coli K-12. J. Gen Microbiol. 134: 1635-1644.

Sun, X., Yu, L., Lan, N., Wei, S., Yu, Y., Zhang, H., Zhang, X., Li, S. 2012. Analysis of the role of transcription factor VAD5 in conidiation of Neurospora crassa. Fungal Genet Biol. 49(5): 379387.

Surfaces. Annu. Rev. Phytopathol., 38, 145 180.

Surfaces. Annu. Rev. Phytopathol., 38, 145 180.

Sweigard, J.A., Carroll, A.M., Farrall, L., Chumley, F.G. and Valent, B. 1998. Magnaporthe grisea phytopathogenicity genes obtained through insertional mutagenesis. Mol. Plant Microbe Interact. 11, 404-412.

Tecsi, L. I., Smith, A. M., Maule, A. J., Leegood, R. C. 1996. A spatial analysis of physiological changes associated with infection of cotyledons of marrow plants with cucumber mosaic virus. Plant Physiol. 111: 975-985.

Timberlake, W. E. 1980. Developmental gene regulation in Aspergillus nidulans. Dev Biol. 78(2): 497-510.
Van Loon, L. C. 1987. Disease induction by plant viruses. Adv Virus Res. 33: 205-55

Ventelon-Debout, M., Delalande, F., Brizard, J.P., Diemer, H., Van Dorsselaer A. Brugidou, C. 2004. Proteome analysis of cultivar-specific deregulations of Oryza sativa indica and $O$. sativa japonica cellular suspensions undergoing Rice yellow mottle virus infection. Proteomics. 4: 216-225.

Voegele, R. T., Wirsel, S., Möll, U., Lechner, M., \& Mendgen, K. 2006. Cloning and characterization of a novel invertase from the obligate biotroph Uromyces fabae and analysis of expression patterns of host and phytopathogen invertases in the course of infection. Molecular Plant-Microbe Interactions, 19(6): 625-634.

Wilkens, S. 2015. Structure and mechanism of ABC transporters. F1000Prime Reports. 7: 14 .

Wohlhieter, J. A., Lazere, J. R., Snellings, N. R., Johnson, E. M., Synenki, R. M. and L. S. Baron. 1975. Characterization of transmissible genetic elements from sucrose-fermenting Salmonella strains. J Bacteriol. 122: 401- 406

Wright, B. E. 1979. Causality in biological systems. Trends Biochem Sci. 4: 110111.

Wyatt, T. T., VanLeeuwen, M. R., Wösten, H. A. B., and Dijksterhuis, J. 2014. Mannitol is essential for the development of stressresistant ascosporesin Neosartorya fischeri (Aspergillus fischeri). Fungal Genet. Biol. 64: 11-24.

\section{How to cite this article:}

Prahlad Masurkar, Raina Bajpai, Vandana Sahu, Munnesh Kumar and Rahul Singh Rajput. 2018. Invasion and Nutrient Acquisition Strategies of Phytopathogens: Fungi, Bacteria and Viruses. Int.J.Curr.Microbiol.App.Sci. 7(08): 3132-3146. doi: https://doi.org/10.20546/ijcmas.2018.708.335 